\title{
FAKTOR-FAKTOR YANG MEMPENGARUHI SIKAP MAHASISWA TERHADAP PERAN JENDER
}

\author{
Binahayati Rusyidi ${ }^{1)}$, Nina Djustiana ${ }^{2)}$ dan Renny Sekarningsih ${ }^{1)}$ \\ ${ }^{1)}$ Dosen Jurusan Ilmu Kesejahteraan Sosial, FISIP-UNPAD
${ }^{2)}$ Dosen Fakultas Kedokteran Gigi dan Kepala Puslitbang Gender dan Anak, LPPM UNPAD
}

Email : titi.rusyidi06@gmail.com

\begin{abstract}
ABSTRAK. Tujuan utama penelitian ini adalah menguji pengaruh faktor-faktor sosial-demografi, sosial-budaya dan keberagamaan terhadap sikap mahasiswa perguruan tinggi mengenai peran jender. Responden adalah 269 mahasiswi dan 179 mahasiswa perguruan tinggi negeri di wilayah Jatinangor, Sumedang, Jawa Barat yang sedang mengikuti perkuliahan semester genap tahun 2012. Responden berasal dari program studi sarjana Ilmu Hukum, Ilmu Keperawatan, Ilmu Kesejahteraan Sosial, dan Ilmu Pemerintahan yang rata-rata berusia 19,7 tahun $(\mathrm{SD}=1,1)$. Penentuan sampel dilakukan secara non- random dengan menggunakan convenience sampling technique. Data dikumpulkan melalui pengisian kuesioner terstruktur oleh para responden. Penelitian ini menunjukkan kecenderungan sikap mahasiswa yang ambigu atau inkonsisten terhadap peran jender. Meskipun secara umum mahasiswa mendukung kesetaraan kesempatan dan peran laki-laki dan perempuan dalam pekerjaan dan pendidikan, sebagian besar masih mendukung adanya segregasi peran laki-laki dan perempuan dalam kehidupan keluarga dan masyarakat yang pada prinsipnya memberikan keistimewaan dan kebebasan yang lebih besar kepada laki-laki. Analisis regresi menunjukkan bahwa jenis kelamin, agama, orientasi kekerabatan, dan tingkat keberagamaan secara statistik memiliki asosiasi signifikan dengan sikap mahasiswa mengenai peran jender. Jurusan, masa kuliah, dan latar belakang lingkungan masa kecil dan remaja tidak menunjukkan asosiasi yang signifikan dengan sikap mahasiswa. Dalam kerangka pendidikan berwawasan jender, penelitian ini merekomendasikan pengembangan metode untuk penelitian di masa yang akan datang. Penelitian juga merekomendasikan pentingnya transformasi dan peningkatan sikap yang mendukung kesetaraan jender di kalangan mahasiswa perguruan tinggi. Materi-materi berwawasan jender perlu diintegrasikan ke dalam kurikulum akademik dan kegiatan kemahasiswaan.

Kata kunci: sikap mahasiswa, peran jender, kesetaraan laki-laki dan perempuan, lembaga pendidikan tinggi
\end{abstract}

\section{FACTORS AFFECTING THE ATTITUDES OF COLLEGE STUDENTS TOWARD GENDER ROLES}

ABSTRACT. The main purpose of this study is to investigate the influences of socio-demographic and sociocultural factors on students' attitudes toward gender roles. The respondents were 269 female and 179 male college students at a state university located in Jatinangor, Sumedang, West Java, who were studying during odd semester of 2012. The respondents were the students from the Law, Nursing, Social Welfare, and Politics study programs. Non- random convenience sampling was utilized to derive the sample. The data were collected using self-report structured questionnaires. The study found that in general the students reported ambiguity or inconsistency toward gender roles. While in one hand, most of students agreed on equality in job and education between men and women, on the other hand, the majority of the participants still segregated the roles of women and men in the family and social domains which principally provided more previleges and freedom for men. Statistical analysis using multi-regression technique found 4 variables significantly associated with attitudes toward gender roles namely sex, religion, religiosity, and kinship system. However, the study program, length of study, and the place where participants spent most of childhood and adolescent times were not associated with attitudes toward gender roles. This study proposed some methodological improvement for future studies. It also highlighted the importance to promote and transform college students' attitudes toward supporting equality in gender roles. Both academic and non-academic activities need to consider gender-sensitive materials to the students.

Key words: college students' attitudes, gender roles, gender equality, tertiary eduation institution 


\section{PENDAHULUAN}

Dalam Millenium Development Goals (MDGs), peningkatan kesetaraan jender dan pemberdayaan perempuan dicantumkan sebagai satu dari 8 (delapan) tujuan pembangunan global. Sikap terhadap peran jender merupakan salah satu faktor yang mempengaruhi pencapaian kesetaraan jender. Karena adanya keterkaitan antara sikap dan perilaku, sikap yang mendukung ketidaksetaran jender akan memfasilitasi keberlangsungan perlakuan tidak adil atau diskriminatif, khususnya terhadap kaum perempuan dalam kehidupan keluarga dan masyarakat (Ridgeway, 1997). Sebagai salah satu agen sosialisasi utama, lembaga pendidikan dituntut berperan serta untuk mempromosikan kesetaraan jender melalui pendidikan berwawasan jender.

Penelitian mengenai sikap mahasiswa perguruan tinggi mengenai peran jender umumnya dilakukan di negara-negara yang kondisi kesetaraan jendernya sudah relatif baik seperti Amerika Serikat (Fan \& Marini; 2000; Bryant, 2003) atau negaranegara yang sedang mengalami transformasi sosial budaya yang sangat substansial seperti Cina dan Lebanon (Zhang, 2006; Abouchedid \& Nasser, 2007). Untuk konteks Indonesia, penelitian serupa telah dilakukan, namun dengan target kalangan pelajar sekolah dasar dan menengah di 4 (empat). Salah satu hasil penelitian tersebut menunjukkan masih cukup kentalnya pandangan stereotip mengenai peran jender (Utomo dkk., 2012).

Tujuan utama penelitian ini adalah menganalisa pengaruh faktor-faktor sosialdemografis, sosial budaya, dan keberagamaan terhadap sikap mahasiswa perguruan tinggi. Hasil dari penelitian ini diharapkan dapat memberikan gambaran mengenai sikap mahasiswa Indonesia terhadap peran jender serta mengurangi kesenjangan pengetahuan tentang faktor-faktor yang mempengaruhi sikap terhadap peran jender mahasiswa Indonesia. Selanjutnya penelitian ini juga diharapkan dapat memberikaan sumbangan pemikiran bagi perguruan tinggi untuk pengembangan pendidikan yang berwawasan jender.

\section{METODE}

Sampel penelitian ini adalah mahasiswa tingkat sarjana yang sedang mengikuti perkuliahan semester genap tahun 2012 di jurusan Ilmu Hukum, Ilmu Pemerintahan, Ilmu Keperawatan, dan Ilmu Kesejahteraan Sosial pada sebuah perguruan tinggi negeri yang kampus utamanya berlokasi di Jatinangor, Jawa Barat. Salah satu alasan pemilihan jurusan adalah untuk melihat apakah terdapat perbedaan sikap mahasiswa pada jurusan yang dikategorikan sebagai domain laki-laki ( Jurusan Ilmu Hukum dan Pemerintahan ) dibandingkan dengan jurusan yang dikategorikan sebagai domain perempuan (Ilmu Kesejahteraan Sosial dan Keperawatan). Teknik convenience sampling diterapkan dengan merekrut mahasiswa yang sedang mengikuti perkuliahan di kelas masing-masing. Responden mengisi kuesioner di dalam kelas setelah membaca dan menyetujui informed consent (lembar kesediaan) mengenai tujuan dan manfaat penelitian, kesukarelaan untuk ikut serta dalam penelitian, kebebasan untuk membatalkan keikutsertaan mereka dalam survey, dan perlindungan terhadap kerahasiaan respon responden oleh peneliti.

Sikap terhadap peran jender merupakan variabel terikat yang diukur menggunakan Attitudes Toward Woman Scale-Short version (ATWS). ATWS terdiri atas 15 pernyataan untuk menggali sikap seseorang mengenai hak, tanggungjawab, dan kewajiban laki-laki dan perempuan dalam kehidupan keluarga dan masyarakat. Misalnya: "suami juga sebaiknya turut mengerjakan tugastugas domestik seperti membersihkan rumah dan mencuci piring" atau "perempuan dan laki-laki harus mendapatkan kesempatan yang sama dalam pekerjaan". Pengukuran menggunakan 4 poin skala Likert dengan skor $1=$ sangat tidak setuju, $2=a g a k$ tidak setuju, 3=agak setuju, dan 4=sangat setuju. Kemungkinan total skor tertinggi 60 dan terendah adalah 4. Skor diinterpretasikan sebagai suatu kontinum di mana skor yang tinggi merefleksikan sikap yang egalitarian atau mendukung kesetaraan jender sedangkan skor yang rendah menggambarkan sikap yang tidak mendukung kesetaraan laki-laki dan perempuan (Helmreich, Spence, \& Gibson, 1982). Instrumen ATWS telah divalidasi dalam berbagai populasi penelitian di banyak negara termasuk Asia dan memiliki reliabilitas yang baik (Lee \& Cheung, 1991; Yick, 1997). Dalam studi ini Cronbach alpha hasil tes reliabilitas ATWS yaitu .70 dan dikategorikan cukup baik. 
Variabel terikat terdiri atas 3 kelompok yaitu: a) kelompok faktor sosial-demografi, terdiri atas jenis kelamin, usia, jurusan, angkatan, dan tempat menghabiskan sebagian besar masa kanak-kanak; b) kelompok faktor sosial-budaya yang meliputi agama dan suku bangsa, serta c) tingkat keberagamaan. Tingkat keberagamaan diukur menggunakan Religiosity Scale ( Haj-Yahia,1998) yang terdiri atas 3 item (misal: frekuensi menjalankan ibadah keagamaan) yang pengukurannya menggunakan 6 poin skala Likert ( $1=$ tidak sama sekali, $6=$ sangat sering/sangat tinggi). Skor yang tinggi merefleksikan derajat keberagamaan yang tinggi dan sebaliknya skor yang rendah menunjukkan tingkat keberaagamaan yang rendah. Instrumen Religiosity Scale telah diuji coba dalam penelitian di beberapa negara dengan tingkat konsistensi yang sangat baik (Haj-Yahia, 1998; 2002; Rusyidi, 2011). Dalam studi ini uji Cronbach alpha internal konsistensi Religiosity Scale juga sangat baik (.81).

Hierarchical regressions digunakan sebagai teknik analisis data dengan menggunakan Software SPSS versi 18. Teknik ini memungkinkan peneliti untuk mengkaji pengaruh satu blok variabel bebas ketika blok variabel bebas lainnya dimasukkan kedalam model regresi. Skor Beta dalam analisa juga dapat digunakan untuk menunjukkan arah dan besaran pengaruh variabel bebas terhadap variabel dengan mengontrol pengaruh variabel-variabel bebas yang lain (Tabachnick \& Fidell, 2007). Dalam analisis regresi, hanya tingkat keberagamaan yang dikategorikan sebagai variabel bebas yang bersifat continuous, sementara lainnya dikategorikan sebagai variabel dummy yaitu jenis kelamin (lakilaki $=0$, perempuan $=1)$, jurusan $(0=$ orientasi pelayanan sosial dan kesehatan; $1=$ orientasi hukum dan politik), semester $(0=\leq$ semester $4 ; 1=>$ semester 4), tempat menghabiskan sebagian besar masa kanak-kanak ( $0=$ kota kecil, $1=$ kota besar), dan agama (non-Islam=0, Islam=1). Suku bangsa dijadikan 3 variabel dummy (orientasi kekerabatan patrilineal, matrilineal dan bilenial). Usia dikeluarkan dari analisis karena memiliki collinearity yang tinggi dengan tingkat keberagamaan. Dalam analisis, setiap kelompok faktor diperlakukan sebagai suatu blok dan dimasukkan ke dalam model regresi secara berurutan. Hasil yang ditunjukkan dalam model terakhir ( ke-3) yang didiskusikan dalam pembahasan.

\section{HASIL DAN PEMBAHASAN}

Sebanyak 448 (empat ratus empat puluh delapan) mahasiswa berusia antara 17-23 tahun berpartisipasi sebagai responden (rata-rata berusia 19,7 tahun, $\mathrm{SD}=1,1$ tahun). Enam puluh empat persen adalah perempuan, $36 \%$ laki-laki. Sekitar 54\% responden menghabiskan sebagian besar masa kecil dan remajanya di wilayah yang dikategorikan sebagai kota besar dan $46 \%$ di kota kecil.

Sekitar 48\% responden adalah mahasiswa semester enam, $31 \%$ mahasiswa semester dua, dan $21 \%$ mahasiswa semester empat. Bidang studi responden meliputi 36 \% Ilmu Keperawatan, 29\% Ilmu Hukum, 22\% Ilmu Kesejahteraan Sosial, dan 13\% Ilmu Pemerintahan. Mayoritas responden beragama Islam $(87 \%)$, sedangkan $13 \%$ adalah penganut agama Kristen Protestan, Katolik dan Budha. Skor rata-rata tingkat keberagamaan adalah 12,4 (standard deviation= 2,4) yang dapat diinterpretasikan sebagai menengah. Sementara itu latar belakang suku bangsa para responden adalah Sunda (52,3\%), Jawa (20,6\%), Batak (11,6\%), Minang (8\%) dan lainnya (Melayu, Betawi, dll).

Secara umum sikap mahasiswa mengarah pada dukungan terhadap kesetaraan laki-laki dan perempuan meskipun kecenderungan tersebut tidak terlalu substantial (rata-rata $=38$, standard deviation=5, 6). Namun demikian analisis detil menunjukkan bahwa mahasiswa dalam penelitian ini masih menunjukan sikap yang ambigu terhadap kesetaraan peran laki-laki dan perempuan. Di satu sisi, sebagian besar mendukung kesempatan yang sama dalam pendidikan dan pekerjaan. Misalnya: masing-masing $89 \%$, 87\%, dan $70 \%$ responden setuju atas kesempatan yang sama antara lakilaki dan perempuan dalam mendapatkan pekerjaan, mengenyam pendidikan tinggi, dan menjalankan jenis pekerjaan yang fleksibel (laki-laki bisa melakukan perkerjaan yang dianggap 'bidang' perempuan seperti menjahit dan sebaliknya perempuan bekerja di "bidang" laki-laki seperti menjadi masinis kereta api).

Namun di sisi lain, mayoritas responden masih mendukung segregasi peran laki-laki dan perempuan berdasarkan domain publik dan privat. Misalnya, masing-masing $76 \%$ dan $70 \%$ 
responden menyatakan persetujuannya bahwa ibu harus diserahi tanggungjawab utama dalam membesarkan anak dan perempuan menikah harus mengutamakan keluarga dibandingkan karir profesional. Selanjutnya, $73 \%$ menyatakan dukungan bahwa kepemimpinan dalam masyarakat harus dipegang oleh laki-laki dan $60 \%$ mendukung pernyataan bahwa suami yang istrinya bekerja di luar rumah tidak perlu terlibat membantu tugastugas rumah tangga seperti membersihkan rumah atau mencuci piring.

Gambaran sikap mahasiswa menunjukkan masih cukup kentalnya pandangan pembagian peran jender yang dikotomis. Laki-laki didukung untuk fokus berkiprah dalam pekerjaan atau mendominasi kepemimpinan sosial. Sementara itu, peran perempuan di dunia kerja akan didukung sepanjang peran domestik yang menjadi tugas utamanya tetap dilaksanakan dengan baik atau bahkan diprioritaskan. Pandangan seperti ini tampaknya merupakan tantangan tersendiri dalam mengurangi beban ganda (double burden) yang banyak dialami wanita bekerja di Indonesia atau meningkatkan peran perempuan dalam kepemimpinan sosial dan politik.

Hasil regresi statistik menemukan 4 (empat) variabel yang secara signifikan mempengaruhi sikap terhadap peran jender: jenis kelamin, agama, orientasi kekerabatan, dan tingkat keberagamaan. Standardized coefficients (Beta) keempat prediktor tersebut masing-masing : .36, -.25, -.18, dan .11. dan menjadikan jenis kelamin sebagai prediktor terbesar dalam model regresi (tabel 1). Sementara itu tidak ditemukan asosiasi yang signifikan antara orientasi jurusan, masa studi, dan tempat menghabiskan masa kecil dan masa remaja dengan sikap mengenai peran jender. Seluruh variabel menjelaskan $45 \%$ dari total variance terkait sikap mahasiswa mengenai peran jender. Ini berarti bahwa sekitar $55 \%$ prediktor sikap mengenai peran jender dapat dijelaskan oleh variabel-variabel lain yang belum dikaji dalam penelitian ini.

Responden perempuan menunjukkan sikap yang lebih mendukung kesetaraan peran jender dibandingkan dengan responden laki-laki ketika variabel bebas lainnya dikontrol ( $B=4,28)$. Temuan ini konsisten dengan berbagai penelitian sebelumnya yang dilakukan di berbagai negara (
Frieze, 2002; Bryant, 2003; Zhang, 2006 ). Kondisi ini tampaknya terkait dengan adanya perbedaan kepentingan antara laki-laki dan perempuan terhadap kesetaraan jender. Pemahaman atau pengalaman negatif yang dialami perempuan akibat subordinasi status dan peran mereka menyebabkan perempuan memiliki kepentingan untuk mendukung kesetaraan yang pada gilirannya akan memberikan lebih banyak manfaat bagi kehidupan mereka. Sementara itu laki-laki masih berkepentingan untuk mempertahankan status mereka sebagai kelompok yang memiliki hak istimewa dalam keluarga dan masyarakat.

Dalam penelitian ini para mahasiswa yang beragama Islam melaporkan sikap yang kurang mendukung kesetaraan peran laki-laki dan perempuan dibandingkan dengan rekan-rekan mahasiswa non-Muslim $(B=-4,16)$ ketika variabel bebas lainnya dikontrol. Pengaruh agama terhadap peran jender juga ditemukan dalam penelitian serupa di kalangan pelajar kelas 12 di provinsi DKI Jakarta, Jawa Barat, Sulawesi Selatan, dan NTB (Utomo dkk., 2012). Walaupun temuan ini menggarisbawahi perlunya penelitian lanjutan untuk memahami pengaruh agama terhadap peran jender, hal ini perlu disikapi secara hati-hati karena beberapa studi lain menunjukkan adanya inkonsisten asosiasi antara agama (dalam hal ini Islam) dan sikap terhadap peran jender di kalangan mahasiswa atau masyarakat umum (Abouchedid \& Nasser, 2007; Seguino \& Lovinsky, 2009).

Penelitian ini menemukan bahwa tingkat keberagamaan berasosiasi negatif terhadap sikap para responden mengenai peran jender $(B=$ 4,22). Semakin tinggi tingkat keberagamaan, maka responden semakin cenderung bersikap tidak mendukung kesetaraan jender. Asosiasi ini juga ditemukan dalam penelitian di kalangan kalangan mahasiswa atau masyarakat umum di berbagai negara (Frieze, et al., Heineck, 2004; Seguino \& Lovinsky, 2009). Namun demikian, Abouchedid \& Nasser ( 2007) menyimpulkan interaksi tingkat keberagamaan dan jenis kelaminlah yang berasosiasi dengan sikap terhadap peran jender, bukan tingkat keberagamaan.

Berbagai kemungkinan dapat menjelaskan pengaruh tingkat keberagamaan dalam penelitian ini. Pertama, meskipun banyak sekali ajaran agama 
yang menggarisbawahi kesetaraan laki-laki dan perempuan, tidak dapat dipungkiri bahwa beberapa ajaran dari beberapa agama diinterpretasi sebagai sumber norma yang mengedepankan supremasi laki-laki atas perempuan dalam kehidupan keluarga dan masyarakat. Temuan ini mengindikasikan bahwa responden dengan tingkat keberagamaan yang relatif tinggi lebih dipengaruhi oleh ajaran agama yang menginterpretasikan status dan peran istimewa laki-laki dibandingkan perempuan. Selain itu, ada kemungkinan bahwa mahasiswa dengan tingkat keberagamaan tinggi cenderung untuk menjawab secara normatif, bukan berdasarkan pandangan mereka yang sebenarnya.

Penelitian ini menemukan bahwa para mahasiswa dengan latar belakang suku bangsa yang berorientasi pada sistem kekerabatan matrilineal (Minang) menunjukkan sikap yang lebih mendukung kesetaraan laki-laki dan perempuan dibandingkan dengan mahasiswa lain yang berlatar belakang kesukuan patrilineal atau bilenial $(B=2,56)$. Asosiasi ini tampaknya terkait dengan posisi dan peran penting kaum perempuan dalam kehidupan keluarga dan masyarakat Minang di mana sistem keturunan dan pewarisan harta pusaka ditarik melalui garis perempuan. Dengan demikian tidak mengherankan jika status dan peran perempuan dipandang sama pentingnya dengan laki-laki.

Awalnya penelitian ini memprediksikan bahwa masa studi akan mempengaruhi sikap mahasiswa. Semakin senior posisi mahasiswa di bidang studinya maka diasumsikan bahwa mereka akan semakin sering terekspose dengan atau mendukung pemikiran/ perilaku terkait kesetaraan jender yang ditansfer melalui kegiatan akademik maupun non-akademik di lingkungan perguruan tinggi. Namun demikian penelitian ini tidak menemukan adanya perbedaan sikap yang signifikan antara mahasiswa yang dianggap junior (semester 2 dan 4) dengan mahasiswa senior (semester 6 atau lebih). Hal ini menyiratkan bahwa transfer nilai-nilai mengenai kesetaraan jender belum terjadi secara substansial di dalam proses pendidikan di perguruan tinggi.

Tabel 1. Regresi Faktor-faktor yang mempengaruhi sikap mahasiswa terhadap peran jender

\begin{tabular}{|c|c|}
\hline & $\begin{array}{l}\text { Model } 3 \\
\mathrm{~F}=13,28(.000) \\
\text { Variabel Bebas } \\
\mathrm{B}(\text { standardized } \beta)\end{array}$ \\
\hline Constant & 43,70 \\
\hline Jenis Kelamin ( $1=$ Perempuan $)$ & $4,27(, 36)^{* * *}$ \\
\hline Semester $(1=>$ Semester 4$)$ & $1,23(, 11)$ \\
\hline Jurusan (1= Hukum dan pemerintahan) &,$- 18(-, 02)$ \\
\hline Tempat menghabiskan masa kecil dan remaja ( $1=$ Kota Besar) &, $21(, 02)$ \\
\hline Agama & $-4,14(, 25) * * *$ \\
\hline Patrilineal &, $33(, 02)$ \\
\hline Matrilineal & $2,56(, 11)^{*}$ \\
\hline Tingkat Keberagamaan &,$- 42(-, 18) * * *$ \\
\hline
\end{tabular}

\section{SIMPULAN}

Walaupun sikap mahasiswa pada umumnya mendukung kesetaraan peran jender namun kecenderungan tersebut belum mapan karena masih diwarnai adanya ambiguitas. Dukungan kesetaraan dalam pekerjaan dan pendidikan tinggi bagi laki-laki dan perempuan tidak serta merta disertai dukungan peran yang setara di dalam kehidupan pernikahan/ keluarga dan kepemimpinan 
masyarakat. Ungkapan 'setinggi-tingginya perempuan bersekolah tapi akhirnya kembali ke dapur juga" tampaknya masih cukup memiliki makna meskipun berbagai indikator menunjukkan berbagai perbaikan dalam kesempatan dan akses perempuan dalam berbagai bidang pembangunan di Indonesia. Temuan mengenai prediktor yang mempengaruhi sikap mahasiswa terhadap peran jender dalam penelitian ini memvalidasi berbagai hasil penelitian sebelumnya yang dilakukan di berbagi negara yang berbeda.

Beberapa hal yang direkomendasikan penelitian ini terkait dengan metodologi dan implikasi penelitian. Studi di masa yang akan datang perlu menentukan sampel secara random (random sampling) untuk meningkatkan kemampuan generalisasi hasil penelitian, memperluas cakupan sampel ke berbagai jurusan eksakta, meneliti berbagai faktor lain yang belum dimasukkan dalam penelitian ini namun dipandang berpotensi mempengaruhi sikap mahasiswa serta menerapkan penggunaan instrumen social desirability untuk mengontrol kemungkinan respon yang bias.

Selanjutnya, temuan penelitian ini mengimplikasikan pentingnya peran lembaga pendidikan tinggi untuk mentransformasi sikap mahasiswa untuk mendukung kesetaraan peran jender baik ke dalam berbagai mata kuliah yang relevan maupun kegiatan kemahasiswaan. Misalnya, pendidikan agama perlu diarahkan untuk membahas tema-tema kesetaraan dan keadilan jender serta menggugah daya kritis mahasiswa untuk mereinterpretasi berbagai pengetahuan atau pandangan agama yang bias jender. Demikian pula halnya pendidikan kewarganegaraan perlu lebih mengangkat isu-isu kesetaraan jender dalam konteks kewarganegaraan dan hak asasi manusia. Selanjutnya forum-forum diskusi mahasiswa perlu difasilitasi untuk mengkritisi kondisi ketidaksetaraan jender yang eksis di kalangan masyarakat. Pendidikan perlu diarahkan untuk membentuk kesepahaman bahwa kesetaraan jender dibangun untuk kebaikan bersama berdasarkan prinsip kerjasama dan saling membutuhkan, bukan kompetisi atau konflik antara laki-laki dan perempuan. Walaupun upaya untuk mengubah sikap tersebut perlu dilakukan terhadap seluruh mahasiswa, titik berat dapat diarahkan kepada pihak laki-laki yang dalam penelitian ditemukan masih menunjukkan sikap yang kurang mendukung kesetaraan jender.

\section{UCAPAN TERIMAKASIH}

Tim peneliti mengucapkan terimakasih dan penghargaan kepada Deviana Yunitasari (FH), Ida Maryati (FIK), Iman Soleh (FISIP) dan , Gigin K. Basyar (FISIP) yang telah membantu pengumpulan data.

\section{DAFTAR PUSTAKA}

Abouchedid, K. \& Nasser, R. 2007. Effects of gender and religiosity among hristians and Muslim on "gendered" roles attitudes toward ability and equity: the case of Lebanon. Electronic Journal of Sociology, 7, 1-18.

Al-Othman, H.M. 2011. Attitudes toward women's participation in public life in the United Arab Emirates. Journal of International Women's Studies, 12 (3), 234-246.

Bryant, A.N. 2003. Changes in attitudes toward women's roles: Predicting gender-role traditionalism among college students. Sex Roles, 48 (3/4), 131-142.

Fan, L. \& Marini, M.M. 2000. Influences of gender role attitudes during the transition to adulthood. Sociology Science Research, 29, 258-283.

Frieze, I.H., Ferligoj, A., Kogovsek, T., Rener, T., Horvat, J., \& Sarlija, N. 2003.Gender-role attitudes in university students in the United States, Slovenia, and Croatia. Psychology of Women Quarterly, 27(3), 256-261.

Haj-Yahia, M.M. 1998. Beliefs about wife-beating among Palestinian women. Violence Against Women, 4, 533-558.

Haj-Yahia, M.M. 2002. Beliefs of Jordanian women about wife beating. Psychology of Women Quarterly, 26, 282-291.

Lee, H.C.B. \& Cheung, F.M. 1991. The attitudes toward rape victims scale: Reliability and 
validity in Chinese context. Sex Roles, 24, 599603.

Rusyidi, B. 2011. Perceptions and attitudes toward violence against wives in West Java, Indonesia. Dissertation. Albany, New York: State University of New York at Albany.

Seguino, S. \& Lovinsky, J. 2009. The impact of religiosity on gender attitudes and outcomes. Diunduh dari website University of Vermont, Amerika Serikat http://www.uvm.edu/ sseguino/pdf/Religiosity .pdf pada 12 Januari 2013.

Ridgeway, C.L. 1997. Interaction and the conservative of gender inequality. American Sociological Review, 62 (April), 218-235.
Tabachnick, B.G. \& Fidell, L.S. 2007. Using multivariate statistics ( $5^{\text {th }}$ edition).Boston: Allyn and Bacon.

Utomo, A., Utomo, I.D., Reimndos, A., \& McDonald, P. 2012. Attitudes to gender roles among school students. Policy Brief No. 7. Canberra: Gender and Reproductive Health Study, Australian National University.

Yick, A.G. \& Agbayani-Siewert, P. 1997. Perceptions of domestic violence in a Chinese American community. Journal of Interpersonal Violence, 12(6), 832-846.

Zhang, N. 2006. Gender role egalitarian attitudes among Chinese college students. Sex Roles, 53 (6), 545-553. 